\title{
STRUCTURES AND MECHANISMS OF COMMUNITY PARTICIPATION IN SCHOOL MANAGEMENT
}

\author{
Tanka Nath Sharma*
}

Abstract

Realizing that community involvement is vital for quality improvement, the government of Nepal decided to transfer the school management authority to the community as a reform measure for school improvement. But the teaching force, one of the important segments of the community is opposing the government's strategies. This paper attempts to discuss significance and importance of transferring management responsibility to the community from the perspective of theory and practice and highlights the benefits and prerequisites based on the review of international practices.

\begin{abstract}
Introduction
Quality education system is one that succeeds in meeting its own goals; one that is relevant to the needs of children, communities and society; and one that fosters the ability of children to acquire knowledge and critical learning skills (GEC, 2002). A high dropout rate in schools is not only the result of poor quality, but if effective learning is not taking place in schools, parents are more likely to withdraw children from school early or not send them at all. Improving quality of education is therefore essential to achieving the 2015 goal of universal access to education. Without active involvement of the community in school management quality improvement is not possible.

Educating is a fusion among the curriculum, teacher and the learner (students) given the favorable learning environment (Gowin, 1994). Curriculum is expected to be relevant to needs and expectations of the learner and the community. Teacher is required to be committed to the children's learning having expertise in teaching having innovative ideas and approaches to maximize learning. Effective teaching requires teachers' understanding of learners' readiness to learning and exploring and applying innovative teaching strategies. To better understand the students (learners) and to identify the best teaching approaches suitable to the learners, frequent interaction of teachers with parents is essential. Learners' willingness to learn is single most criteria of educating. Similarly, without community support and involvement, school alone cannot create appropriate learning environment to enhance children's willingness to learn. Quality education requires the collective efforts of teachers, students, parents and community. This paper presents concept and importance of community involvement in school management and issues and challenges associated to it.

School of Education, Kathmandu University
\end{abstract}




\section{Emerging Guiding Concept}

The most striking feature of educational systems in Nepal and other developing nation today is change. Nepal's dramatic shift toward open economies, democratic governance, and commitment for decentralization has made education crucial to continued economic success and social development. Global competition requires workers with foundational knowledge who understand science and technology and can adapt to rapidly changing conditions. Democratic rule requires citizens who are better informed and more responsible. The decentralization of public administration is placing a new emphasis on citizen participation, autonomy, and responsibility in district and municipal settings.

Successful schools do not operate in isolation. They build connections to parents and communities as a way to strengthen relationships in support of the students, and as a way to better understand students so that teaching can be tailored to them as individuals. Communities offer a wide range of resources that are valuable to schools and the families they serve. These resources include people who volunteer their time in the school, organizations that offer enrichment opportunities, businesses that offer career-related information and workplace experiences, and agencies that provide various social services for students and families. Communities too are rich in untapped resources that can benefit children. International experiences revealed that when families and community members volunteer their time and talent in the schools, both schools and students increase their capacity to do more and to do it better. Therefore, it has been realized in many countries that community involvement is vital to the effective teaching and learning.

Empowering local community to take charge of educating their children is the foundation of effective school community relation. The shift to increase community control of schools can be seen as a move to enhance and reframe democratic right and participation. Instead of top-down administrative decision-making, a broader base of constituents should be included in shared educational decision making. These reforms to empower community present educators with new and previously unknown challenges.

The professional school as an entity needs broader and inclusive boundaries that can capture educational needs and expectations people from various background and status such as social class, gender, race, economic status and ideologies. The social exclusion is to be replaced by multiple voices and multiple concerns about school, its performance and management. Part of the teachers' and administrators' education has to be learning how to change organizational structures to reframe school-community relations as collaborative, to relate to and communicate with community in all their diversity. To be a professional educator would include the ability to relate to and team with a variety of people and organizations - such as parents, citizens, and social agencies. Educational administrators and educators should be prepared to change their traditional ways of managing school and educating children shift toward intense community participation involvement in the process of managing school.

Education is a major concern of the community and their participation and involvement in school management is essential because:

1. Parents have a right to be involved in managing schools where their children are receiving education.

2. Schools can learn from parents' intimate knowledge of their children. No one knows the child better than their parents, and parents and community members are likely to take a child's perspective and to advocate the children's rights in making occupational decisions.

3. Involvement of the community facilitates the relation between the school and community. Relationship with parents and community 
may be a way to avoid unexpected intrusions and to reduce antagonism between community and school. Bringing parents, teachers and school together in shared decision- making is a way to reduce "adversarial relations" and to contribute to better decision making.

4. Community can provide much needed resources and other volunteer support to the school, such as financial, free labor and expertise.

5. The involvement of community can improve school accountability and make school more responsive to community needs.

6. Enhancing community and parents' participation in the school may help increase students outcome. In other words, community's involvement enhances parental involvement and parental involvement in schooling in itself is believed to have positively affect children's 'achievements, attitudes, and aspiration, even after student ability and family socioeconomic status are taken into account.

In developed countries, community participation in the management of schools demonstrated a lot benefits that included were ownership of the schools by communities, willingness of the communities to support the schools financially and materially, and the schools becoming environments where democracy is practiced. According to Epstiein (2000) the following six standards have to meet for effective involvement of communities in school management:

1. Communication: Communication between home and school is regular, two-way, and meaningful.

2. Parenting: Parenting skills are promoted and supported.

3. Student Learning: Parents play an integral role in assisting student learning.
4. Volunteering: Parents are welcome in the school, and their support and assistance are sought.

5. School Decision Making and Advocacy: Parents are full partners in the decisions that affect children and families.

6. Collaborating with Community: Community resources are used to strengthen schools, families, and student learning.

In short, the involvement of the community in the school makes good sense for several reasons: to gain access to knowledge that parents have of their children; to make better decision; to enhance learning opportunities; and to build support for schools. School may need to work with parents and others in the community, not by demanding more from them, but by focusing on the people of the community and their needs and by figuring out how the community can be an integral part of the educational conversation.

The community partnership is a natural expansion of the parent-school partnership. In a community you can get concerned community members, elected officials, business representatives, religious leaders, and many others involved in ways that support student learning. The framework below describes the process and capacity of involvement of community in school management:

\section{Community Participation Stages}

Community participation and involvement follows the process exhibited in Fig. 1 below. Participation and involvement of the community in the management and improvement of school follows the following process if we want to accomplish the desired level of outcomes. First, the community should have an access to be in the school, learn about the school and observe what goes on school. This process raises curiosity among the community members. The second step would be to make community aware of the situation and make them realize the importance of their involvement in schools where their children are receiving education. 
With the realization of the importance of their involvement in the management process of the school where their children are learning, they will be ready to get into the process of involvement. Active involvement will lead to decision making and be a part of school governance. These stages of involvement are sequential and communities are expected to practice step by step process of participation and involvement in order to take responsibility of school management.

Fig 1: Community Involvement Model

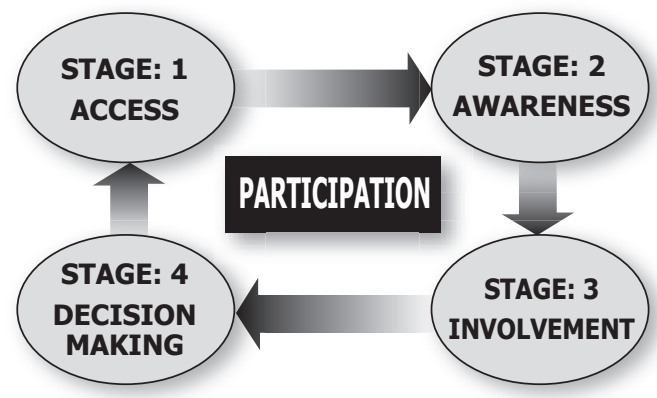

Modalities of Community Involvement in School Management

Many modalities are discussed international arena; however there are some terminologies are used in common. Some of such terminologies are: "Grass - root approach," "Top down approach," Bottom up approach," "Upstream approach," "Trickle down approach," "self help approach," "Integrated approach," "Basic needs approach," "Localization" and "Decentralization". Whatever terminologies used for community participation, the participation and involvement of communities following modalities or approaches:

1. First Approach: Volunteer involvement, or influence on right -based outcomes through political or administrative engagement.

2. The second approach: Active, affective or indifferent involvement in management schools,

3. Third approach: Institutional involvement e.g. serving as the members of management committee or parent teacher association or as members of $\mathrm{NGOs} / \mathrm{CBO}$ s

4. Fourth Approach: Natural involvement of parents, teachers, students without them school can not be functional.

In terms of governance and management schools can be categorized in to following types:

\section{Shared responsibility of central and local government but managed locally}

A shared responsibility between state and local government for educating children is the main theme of this model from which the central government establishes a mechanism through which the funds are channeled to local government based on agreed per child cost percentage and local government has to supplement additional needed costs to schools through their collected revenues. The local government is made accountable to provide quality education through the formation of school boards/ committee/ trustees with adequate authority represented by the major stakeholders (parents, teachers, students and community members). A system of accountability assessment based on set standard would be in operation to ensure transparency, performance and quality.

\section{Publicly funded/publicly managed}

This model does not empower governing body and resembles as a caretaker body of school for smooth running of schools. In other words, this model represents bureaucratic decentralization by which some authority are given to lower level of units even to schools in order to address local needs. The government units like education division/ block/ circuit control over schools through the provision of school supervisor and principal. The school committee might be formed under chairmanship of local inhabitant/ principal for the support of school requirements but the resources 
require for school maintenance is basically met by public fund. However partnership for quality education can be established with corporate bodies. The Parent Teacher Association (PTA) is generally found in the form of advisory form. Even so, school is made responsible to make their progress in parent meeting.

\section{Publicly funded /community managed}

This model advocates the sprit of partnership between and government and the local community. The school governing board, usually elected or nominated by community groups to represent them, comprising parents, community members, teachers, and students (non-voting power). The basic feature of this model is- deregulation, semi-autonomy, parental domination, and accountability tied with transferred authority. The government is made responsible for providing basic operational cost including salary cost of teachers and the community is made responsible to supplement additional funds to bridge the gaps along with the authority of staffing, budgeting and implementing school plan.

\section{Privately funded and managed}

This model suggests an institution, established by a separate act or procedure having own control over management and finance. Such schools are operated and managed within the general regulatory framework of the government. The structure of governance and areas of services are clearly defined in their laws/ by laws submitted in the process of establishment. Privately funded and managed schools are either profit making or non-profit making. Investors and founders have the full authority and school management committee serves in an advisory capacity.

\section{International Practices}

Silwka \& Istance, (2006) reviewed the structure and practices of community involvement in school management of various countries. Based on the review structure and practices of some countries is presented in the following section.

In Denmark, parents have long played an essential role in running of schools, including the folkeskolen. The role of parents in school decisionmaking was further strengthened in 1990 with the creation of boards of school governors. Each board consists of 5-7 representatives among parents whose children go to school, including two representative from school and two from students. The board of governors is responsible for developing guidelines for school's activities, approving the school budget and deciding the curriculum and staff matters. A report published in 2001 claimed that Danish parents are very committed to their children's schooling and spend an average of three hours in a month at the school.

In England, the governance of schooling consists of enhanced power at the center combined with much greater autonomy of decision-making by schools themselves. Each school has its own governing body which consists of 9-20 governors per school represented from and appointed by different stakeholders. For example, parents and staff members elect their respective governors, whereas, additional community governors are nominated by the governing body. The main functions of the board of governors are: (a) to provide a strategic direction, (b) act critical friends, (c) ensure accountability, and (d) participate in decision-making in wide range of areas. The governing boards also play a core role in staffing a school, dealing with new appointments, staff appraisal and grievances.

In Finland, parents play a significant role in school development after the new Basic Education Act of 1999, which requires schools to be developed in cooperation with parents. The 
schools can design their own curricula based on the National Framework of Core Curriculum. This process, including parent-teacher meetings, school festivities, parents' meetings, discussion events and one-to-one discussions between individual teachers and parents, which has brought school operations closer to parents. Similar decentralization forms of situation and parental involvement prevails in Poland as well.

In Austria, a schools autonomy scheme was initiated since 1980s for enhancing the involvement of parents and students in school management. A board is constituted from parents' representatives elected by representatives voted by parents of students in each class. Teachers' and students' representatives are also included in the board, which is chaired by the principal. Since 2000, elected school boards consisting of parents and other community representatives control the management of schools and its employees.

Spanish parents can participate in the school management through two parent association: Spanish Confederation of Parent Associations (CEAPA) and National Catholic Confederation of Parents (CONCAPA).

The new policy has been initiated for greater parent and community involvement in school management in Japan. The newly introduced 'school councilor system', aims to promote the cooperation of community, residents and parents in the life of the school. The 'school councilor system' also aims to make plans, evaluate the performance for quality enhancement and make achievements of the school management accessible to a wider public in order to create a strong accountability. In addition, Japan has created provisions for the establishment of socalled community schools (similar to Nepal), which are sensitive to local needs and co-managed by community representative who recruit the school principal through an open-application and selection system.

In 1993, UNICEF granted the Children's Peace Award for Education to the Government of the
State of Minas Gerais, Brazil in recognition of its unprecedented efforts to reducegrade repetition by decentralising its education system. The purposes of decentralizations were to: (a) strengthen school administration, (b) provide financial, administrative and pedagogical autonomy, (c) develop and enhance human resources working in education, (d) make the evaluation of teaching independent and (e) integrate the state and the municipality to achieve a single public network of education.

Under the decentralized framework of education in Brazil, the school board having the authority and responsibility of school management typically consists of six members of the external community (students and parents) and six members of the internal community (teachers and school employees), which is chaired by the elected principal (Machado, 1996). At present, the principal cannot determine about the schools including utilizing the resources without the approval of the board. Studies in Brazil claimed that that there is a high correlation between the degree of community involvement and student's achievement. Another significant change in direction saw principals elected by the communities they served, rather than appointed as was the case before. A school's first step towards autonomy is the freedom to choose its own principal since to mobilise the school community you need a principal who is a leader. Due to the provision of selecting the principal by the community and their active involvement in managing schools, the teachers and principals are reported to have greater accountability to parents and students.

Believing that the administrative and financial issues are starting to work well, planners are now beginning to address pedagogical issues and to request that all schools be granted pedagogical autonomy. The idea is to allow local schools to create learning environments that are relevant to the students' daily lives. Brazilian experience demonstrated that for pedagogical autonomy to take effect, it is first necessary that financial 
and administrative autonomy be consolidated. The program evaluation report revealed that involvement of the community in school management contributed to the increase in enrolment, remarkable fall in grade repetition rates, and increase in the school's request for teacher training and retraining as per their needs, improve in teachers' satisfaction and enhanced readiness of community to participate in improving schools without additional cost.

A similar effort was made in Botswana by empowering community to participate in school management. The government proposed that the community schools would be based on community financing and stressed community participation in school management, curriculum development, utilization of school facilities and improvement in the quality of school. Because of poor communication between the government and local communities, inadequate financial resources for school construction, inability to address community needs in the curricula, low education levels of community members, teachers' inability to link instruction with the local culture, community school scheme failed in Botswana.

\section{Community Involvement in School Management in Nepal}

There were no schools in the ancient period in Nepal. Children were taught at their homes or in "Gurukuls" in respect to social norms, values, faith and ideals of life. Education was also provided through Sanskrit education centers, Buddhist "Gumbas" or "Bahals", Muslim religious centers (Madarasa) and Guthis. In the passage of time, community used to keep teachers to teach their children by raising money to pay the teacher's salary with a provision for food and shelter for the teacher. This practice marked the beginning of the community participation in education or educating their children.

In Rana Period (prior to 1951), education was restricted to the general public. Schools were not allowed to open even if the community wanted. There were very limited numbers of schools only for the children of the ruler class and elite. Only after the dawn of democracy in 1951, people were free to open schools for their children. Communities all over the country started to open up school with their own resources and initiative. The government gradually joined hands with the community in the development of schools with the provision of grants. Majorities of the schools set up under the popular initiative were operated mainly on the basis of different types of support available from the people in the communities.

The introduction of Panchyat polity in the country brought changes in the education policy. The government appeared to be more interested in consolidating the structure of educational administration in the country. The government was also anxious to implement programs of mass appeal from the national perspective as well as international demands for the universalization of education. It is interesting to note that there have been quite a few genuine efforts in this period for implementing the recommendations of various commissions. One of them was the idea of universal free primary education and the vocationalization of secondary schools.

In spite of these development measures and changes the management of individual schools at the local level remained basically unaffected in general. The schools established by people remained to be managed by the school managing committees. The government maintained the policy of partial assistance for schools operated under private or community support. It continued to provide differential annual financial grants to schools. The SMCs had responsibility and authority to generate funds to operate schools, the appointment of head teacher and teachers and fixing and payment of their salaries. At the time the financial sources of schools were mainly the student fees and donation of land by some wealthy families or landowners. 
With the inception of New Education System Plan (NESP 1971-76) the state policy in education transformed from a position of least involvement of the community to a position of highest involvement of government in the educational development of the country. NESP was an outcome of experiences and recommendations made by various commissions and experts. Through NESP, for the first time in the country, investment in education was officially recognized as an investment in national development.

The NESP brought notable structural as well as administrative changes in the education system of Nepal. The school education was put under the Directorate of Education placed in each of the regions (originally 4 and later on 5 in number in 1982. District Education Office was made the main field agency for the administration and supervision of the system of school education. The school education was structured as 3 years of primary education, 4 years of lower secondary and 3 years of secondary level. The secondary education had three streams as general, vocational and Sanskrit. Different types of schools existing before the implementation of the NESP were brought under the umbrella of national schools governed by a national curriculum structure. The highest body responsible for the implementation of the program was National Education Committee.

In order to secure local support zonal and district level education committees were formed. The responsibility to mobilize the local resources rested with the district education committees. Above all, the total school administration was made responsible to district education office. In the beginning, the plan had no provision of school level committees like the school management committee in the pre-NESP period. Later in 1974 School Assistance Committees were formed. These committees were not provided with management authorities. They were made ancillary bodies to the DEOs. This arrangement had adverse effects in community support to education. With the increased government control over school management and funding a significant fall in local participation was observed. The plan gave a general feeling among the common people of the country that education was nationalized and communities had no role to play in the management and development of schools. Because of the nationalization of the education system in Nepal, community involvement and community's sense of ownership continued to be faded away (Pant, 2001).

\section{Community Involvement in Schools after the Restoration of Democracy:}

There was a provision for School Management Committee after 1991 for managing public schools. The District Education Office used to nominate management committee usually under the influence of political party on power. The Chairperson and the members of the management committee were less concerned with the quality of education since their children were not enrolled in those schools.

In spite of the importance of parent's involvement and their potential contribution to the school improvement efforts, their role in supporting quality learning in the school is often ignored. In the past, parents had no say in the relation to school management legally. A study has reported that only very few schools invited parents in schools to discuss child learning. The same study found only $10 \%$ of the total parents making inquire about their children's learning. Based on the findings, the Institutional Analysis team made two generalizations about schoolcommunity relations. First, parents did not see themselves as having any defined responsibilities for the learning of their children. Second, teachers ignored the fact that parents and community could play an important role in supporting quality learning.

\section{Current Structure of Community Involvement in} School Management

The government has now realized that the local communities should be involved to manage 
schools. The Tenth Plan emphasized to transform the school management authority to the local community in order to enhance the quality of education and promote the sense of ownership among the member of the community. Considering the importance of the involvement of parent, community members, social workers, several literatures and international development agencies supported the idea of involving the local community members as the most appropriate decision makers of schools school affairs (Brays, 1999; World Bank, 1994; DANIDA, ADB, 2003); HMG/ADB/DANIDA, 2002 ). Such involvement expected to enhance the process of decentralization and transform the school as a self managed school. Due to the immense pressure from the international community and government's own realization of the importance of community involvement in school management, Education Act (Seventh Amendment) (2001) was passed and laid the foundation for decentralization of management of public schools. The 7th amendment of Education Act has empowered the SMC and contributed to facilitating the process of decentralization. The ultimate intent of $7^{\text {th }}$ amendment was to ensure better educational management, empower the capacity and competencies of local bodies and communities in educational planning, management, organization, evaluation, supervision and control over the schools. The Act was also instrumental to protect the local level interests and tried to make SMC more responsible.

\section{Structure and Practices of Community Involvement in School Management:}

The new provision for the SMC in the 7 th Amendment has wide implication in the implementation of educational programs and plans. The composition and structure of School Management Committee expected to have a significant influence in improving the management efficiency, efficiency related to planning, monitoring, supervision and evaluation of the schools, forming and implementing educational programs at the schools and quality improvement. Besides, enhancing public participation in school affairs, and strengthening school community relations, the new provision of forming and functioning of SMC anticipated to have positive impact in schools. More specifically, the Act opened up the avenues for wider participation of the community in developing school improvement plans and engaging in solving emerging problems within the schools.

There is a legal provision for electing four representatives from guardians or parents including one female member in the management committee. These members and chair person of SMC are elected from the gathering of parents/ guardians of students studying in that school. The ward chair person of the respective ward will join the committee. One representative elected by the teachers, one educationist and donor representative or founder member nominated by the SMC will become the member of the committee. The Head Teacher serves as the Member Secretary of the committee. For schools running technical and vocational courses, there is a provision for nominating two representatives of local Chamber of Commerce and Industries. The school supervisor or resource person of respective school is invited as non-voting member in the SMC. This management committee structure is as powerful as any committee or school board structures of developed countries where community involvement in school management is effective.

Nepal has another community involvement and support structure- Parent Teacher Association (PTA) - to facilitate students learning. The SMC will organize a gathering of parent and teachers to elect minimum three and maximum eleven member Executive Committee of PTA. PTA's main purpose is to enhance participation of the community in the educational reform process and strengthen the relations between the community and schools. Main functions of PTA will be to strengthen the quality of teaching learning, advise 
the school about fees structure, and communicate the parent and community about the educational programs of the school. PTA is the supporting wing of SMC for enhancing education quality.

Provision of District Education Committee and Village Education Committee is another effort that attempted to facilitate the process of decentralization on the one hand and worked as a foundation for promoting the local participation at schooling affairs on the other. Due the absence of elected representatives District Development Committee and Village Development Committee, DEC and VEC currently are nonfunctional.

Reflecting the widely shared public perception that nationalization of schools was a mistake, the Seventh Amendment of the Education Act was passed in 2001, which articulated the policy of devolving school management responsibilities to communities (Awasti \& Lekhak, 2005). In 2002, the Government embarked on the transfer of management of public schools all the way down to the community level, by offering all communities the option of taking over public primary schools financed on a block grant basis, subject to meeting some basic prerequisites. Transfer of management of public schools to communities is one of the basic strategies of the Tenth Five-Year Development Plan and the Poverty Reduction Strategy Paper aimed at achieving the Education for All and MDG targets by raising the efficiency of investments in school education. The lessons learned from this will help to achieve the EFA/ MDG targets.

With assistance oftheWorld Bank, thegovernment has started handing over the management of the government schools to the communities from the fiscal year 2002/03 to provide timely and standard education in those schools (World Bank, 2003). By the year 2006, the government schools handed over to the communities comprises 1,973 primary schools, 208 lower secondary schools and 109 secondary schools. During the fiscal year 2003/04, the local communities refused to take over the management of the government schools due to the ongoing conflict in the country, but after the restoration of peace in the country, more and more communities are being attracted towards taking over the management of the schools. Department of Education has issued guidelines for the purpose of clarifying the roles of community, government, financing modalities and other requirements of management transfer (DOE, 2004). The directive has attempted to clarify management-related mechanisms such as teacher management, school improvement plan support, school community relations, and arrangements concerning monitoring, evaluation and supervision of schools. However, teachers' community is strongly opposing the government's policy of transferring school management authority to schools.

\section{Issues and Challenges}

Although participation and involvement of community in school management has produced positive results and improved performance in schools in many countries, Nepal is experiencing several issues and challenges in the process of transferring school management authority to the respective communities and facilitating them to resume the responsibility. Some of the pertinent issues are as follows:

1. A Bureaucratic national system with a decentralized education agenda: A centrally controlled education administration system is reluctant to share power with the community. Such reluctance is reflected in the existing Education Act in which the community involved SMC s are provided with adequate responsibilities without authority. Our cultural practice, values and work system is restraining the power sharing, facilitative, collaborative approaches and attitudes toward community influence our work system and practices needed to promote decentralization in which national system adopts democratic culture of openness and trust. The challenge is how to 
transform centralized bureaucratic national system into a decentralized, democratic and facilitative system of administration.

2. Participation of hard core group in school management: Legal provision for participation of community groups in school management does not guarantee the equitable representation of hard core groups and poor communities whose children represent the majority in the Nepalese public schools. The challenge is how to address the diversity of demand and create a mechanism allowing the "clients" of education to express their interest with regards to the provision and structure of schooling.

3. Collaborative Support from Teachers' community: Teachers are the main players of school reform process. They are the one who facilitate community participation and involvement in school affairs and inspire and mobilize community groups in school improvement initiatives. Research findings (Gamge \& San Antonio, 2006) show that allowing teachers and stakeholders to take part in decision making results in employee satisfaction, motivation, morale and selfesteem. In many countries, the Head Teacher leads the empowered School Board consisting of the community representatives. How to make teachers' community supportive towards transferring school management authority to the local communities in Nepal is a challenge.

4. Communication and interaction with the stakeholders: Much of the problems concerning involvement of community in school management and empowering them to take charge of school affairs have been aroused from inadequate information, interaction and communication. Prior to implementing the scheme of transferring school management responsibilities to the communities, there had to be adequate interaction and communication between the government and the stakeholders.
5. Institutionalization of Community Participation: Structure alone can not bring communities closer to school management. There has to be an established system of facilitating, inspiring and responding respectful environment to promote community involvement and participation in school affairs. The challenge is how to institutionalize such practices in schools.

6. Quality and competitiveness of public schools: The main purpose of involving community in school management is to enhance quality, create conducive physical and learning environment for children, ensure transparency and accountability in school management and improve overall performance of school. The challenge is how to bring such changes through community participation in school management is a challenge.

7. Monitoring and accountability assessment: Authority and autonomy goes along with accountability. How empowered communities are to be made accountable to the results they produce. The challenge is to develop a realistic and implementable accountabilitysystem toensureaccountability at all levels of education management.

8. Manyunanswered questionsand issues: There are many unanswered questions concerning transformation of school management authority to local community. Some of the questions or issues are relato: funding mechanism, head teacher and teachers' role, alienated SMC, teachers professional development, teachers' job security and accountability, teachers/head teacher more responsible to $\mathrm{DEO}$ than to the SMC, SMCs are kept on dark, dominant involvement of elites SMC, inadequate support and facilitation to enhance SMC's capacity to manage schools, control mechanism, SMC's authority to select teachers/principals etc. 


\section{Critical Reflection}

Schools in Nepal are not responding to these new demands. More children go to school now than ever, but the education that most receive falls far short of the requirements for economic success and social advance. The national assessments of grade 3, 5 and annual School Leaving Certificate examination results demonstrated very poor academic performance of students indicating that community schools are performing the way they should.

The problems are striking. Nepal has the high repetition and dropout rates, with nearly a third of all primary students repeating a grade each year. Only half the students who begin primary school will complete the cycle, leaving far too many children without a basic mastery of language and mathematics. A cohort analysis done by World Education demonstrated that $85 \%$ of the students enrolled in grade one drop school before completing secondary education.

Teachers tend to be poorly trained, to have a low status, and to have few incentives for professional excellence. Pedagogy is dominated by the "frontal" model that rewards the memorization of facts and fails to develop student capacities to question, explore, work in groups, and learn on their own.

Educational systems are also remarkably inequitable. Students from the poorest families score dramatically lower on achievement tests than do middle- and upper-class children. Most primary-school repeaters are poor and attend low-quality public schools. For much of the region, good education is still a privilege of the wealthy and upper-middle classes, given at expensive private schools. This scenario in school education is not only the case of Nepal; it applies to many of the developing countries having similar economies.

The question arises does the scheme of involving community in school management improves the situation described above? The answer to this question is not easy. With adequate support from the government, strong leader who can build trust among stakeholder and inspire community to actively involve in school affairs may make the difference (Gamge \& San Antonio, 2006). School leaders wishing to enhance the level of trust among the stakeholders in their school should en

\section{Suggestions}

1. Community readiness to accept the responsibility is an essential prerequisite for community involvement in school management. Adequate time and effort need to be applied making community ready (ability and willingness) to resume the responsibility. The government should follow sequential steps of participation and involvement namely access, awareness, involvement and decision making.

2. Clear information through active interaction with the community is essential to sustain community involvement. The following initiatives are needed to create the environment to encourage community to participate in school affairs:

a. Adequate legal base for community participation in school management,

b. Capacity development of community members to manage resources at the community level,

c. Empower community by involving them in the decision process by developing school leader capable of introducing innovative approaches of education management by encouraging decentralization, involvement and collaborative school governance (Gamage \& San Antonio, 2006).

d. Make community aware of the importance of community participation and involvement in school management. 
3. The government should provide the facilitative support to the community during the initial years to make community active and capable of executing assigned management responsibilities of school management. There has to be adequate input in the capacity development of the SMCs, PTAs, and VECs.

4. Active involvement of head teacher and teachers in the promoting the participation of community in school management is very essential. Therefore, the government should negotiate with teachers to adopt the comfortable structure, system and practices acceptable to them so that they will be the active partners of decentralization process.

5. The government should come with the clear view concerning the funding structure, teacher management, accountability assessment, reward structure of superior performance, capacity development and professional development scheme and clarification of roles of major stakeholders.

\section{Conclusions}

Decentralization is advocated by several policy documents and several literatures (MOES, 2003; GON/ADB/DANIDA, 2002). These literatures advocate that decentralization in education should be the main strategy for implementation of basic and primary education. It has been anticipated to have a strategic shift from centralized and bureaucratic controlled management to community controlled and school-based planning and management in collaboration with various partners such as local bodies, NGOs, INGOs and CBOS (MOES, 2003). It is well accepted fact the schools were created, developed and managed by the communities. It is their right to manage the schools where their children are studying. Since the school education is public good, it is the responsibility of the government to support, facilitate and empower communities to effectively manage the schools and ensure the quality of learning in schools.
The strategy of decentralization and involvement of community in school management is considered as the key to success to education development and reforms. Transferring the school management authority is a strong strategy for school improvement but not the end solution. Access to information, awareness, and involvement in the day to day affairs are the initial steps for enhancing the capacity of community members to take part in decision making related to school affairs. To ensure the proper utilization of authority and resources, an accountability assessment system should be in place..

\section{References}

Awasthi, L. D. \& Lekhak, H. R. (2005). Policy extracts and synthesis of school visit findings: School management. Kathmandu: MOES.

DOE, (2004). School grant operational guidelines, 2061. Sanothimi, Bhakatapur: Author.

Epstein, J. (2000). Johns Hopkins University A monthly newsletter by the National Clearinghouse for Comprehensive School Reform (NCCSR) January 2000 Vol. 1, No. 2 web site at http://www.pta.org/ programs/invstand.htm

Gamage, D. \& Antonio, D. S. (2006). Effective Participatory School Administration, Leadership and Management: Does it affect the Trust Levels of Stakeholders? In http:cnx.org/content/ m14112/latest/

GEC, (2002, May). A Quality Education for All: Priority actions for governments, donors and civil society. GEC Briefing paper.

GON/ADB/DANIDA (2002). Secondary education support program: Core document. Kathmandu: Author.

Gowin, B. (1994). Educating. New York: Cornell University Press.

Henry, M. H. (1996). Parent School Collaboration: Feminist Organizational Structure: New York: State University of New York Press.

Kunda, Z. (2005). Influencing national policy making in education through best practices: Civic involvement in primary education (CIPE) project. OSI education conference 2005: Education and open society: A critical look at new perspectives and demands 
Machado, A. L. (1996, July). Community involvement: School-based management takes root in Brazil. Education News, Issues $17 \&$ 18/Vol. 6, 3, pp. 29-34, UNICEF.

MOES, (2006, October). Concept paper on school sector approach. Kathmandu: Author.

MOES, (2003, May). EFA (2004 - 2009) Core document. Kathmandu: Author.

Pant, Y. R. (2001). Community Support to Education: Research Study Report. Kathmandu Nepal: Danish Support to Secondary Education.

Reid, N. J. (2000). Howpeoplepower bringssustainable benefits to communities. USDA Rural Development, Community Development Office.
Silwka, A. \& Istance, D. (2006). Parental and Stakeholder 'Voice' in Schools and Systems. European Journal of Education, 41(1).

Townsend, T. (1994). Community involvement: The Hidden Factor in Devolution. International Journal of Education Management, 8(4), pp. 24 -29 .

Wilcox, D. (2007). Community participation and empowerment: Putting theory into practice. Joseph Rowntree Foundation.

World Bank, (2003). NEPAL-Community School Project: Kathmandu: Author. 